Article

\title{
Skinner and Merleau-Ponty's Criticism of Causality
}

\author{
Henrique Mesquita Pompermaier* \\ Orcid.org/0000-0003-3002-6503
}

\begin{abstract}
Universidade federal do Rio Grande do Norte, Faculdade de Ciências da Saúde do Trairi,
Santa Cruz, RN, Brasil
\end{abstract}

\begin{abstract}
A strong connection between explaining phenomena and identifying causes is commonly observed not only in philosophical, but also in scientific and common sense discourse. Nonetheless, critical analyses conducted in philosophy of science, especially as of the twentieth century, questioned this tacit connection, to the effect that a scientific explanation does not necessarily imply identifying causes. Examples of this viewpoint applied to discussions of psychological phenomena can be found in various traditions, such as M. Merleau-Ponty's existential-phenomenology and B. F. Skinner's radical behaviorism. The present paper seeks to highlight the criticism of causal theories, discussing the fundamental contribution of such criticism to treating behavior as a phenomenon with its own sense, as was proposed in MerleauPonty and Skinner's approaches. Both approaches claim that explaining behavior does not signify identifying causes, but rather describing either the structure of behavior, according to Merleau-Ponty, or the contingencies of reinforcement, according to Skinner. Along these lines, we recommend such criticism as an element favoring potential closeness and dialogue between these different perspectives.
\end{abstract}

Keywords: Causality, explanation, Skinner, Merleau-Ponty.

\section{Críticas de Skinner e Merleau-Ponty à Causalidade}

\section{Resumo}

Encontra-se, tradicionalmente, uma forte identificação entre explicação e causa, tanto na filosofia, quanto na ciência e no senso comum. Contudo, revisões críticas instauradas no âmbito da filosofia da ciência, particularmente a partir do século XX, questionam essa identificação tácita, de modo que uma explicação científica não implica necessariamente em apontar causas. Exemplos dessa compreensão aplicados a discussões com relação a fenômenos psicológicos podem ser encontradas em diferentes tradições, como a fenomenologia-existencial de M. Merleau-Ponty, e o comportamentalismo radical de B. F. Skinner. Este trabalho busca salientar a crítica em relação ao pensamento causal, discutindo seu papel fundamental para a abordagem do comportamento como fenômeno com sentido próprio, como pretendido nessas duas perspectivas. Em ambas as abordagens, explicar não é encontrar as causas, mas descrever, a estrutura do comportamento, para Merleau-Ponty, ou as contingências de reforçamento, para Skinner. Nesse sentido, indica-se essa postura crítica como elemento favorecedor de possíveis aproximações e diálogos entre essas diferentes perspectivas.

Palavras-chave: Causalidade, explicação, Skinner, Merleau-Ponty.

* Mailingaddress:Rua Vila Trairi,s/n, Centro, SantaCruz,RN,Brasil,59.200-000.E-mail:henriquepompermaier@ gmail.com.

By the period this paper was submitted and accepted, the author have financial support from: Bolsa Fundação de Amparo à Pesquisa do Estado de São Paulo (FAPESP) de Doutorado, processo n $2013 / 25363-9$. 


\section{Las criticas de Skinner y Merleau-Ponty a la causalidad}

\section{Resumen}

Observase tradicionalmente una identificación fuerte entre explicación y causas, tanto en la filosofía cuanto en la ciencia y el sentido común. Sin embargo, revisiones críticas desde la filosofía de la ciencia, sobre todo a partir del siglo XX, cuestionaron esta identificación tácita, por lo que una explicación científica no implica necesariamente apuntar causas. Ejemplos de esta comprensión aplicada a los debates sobre los fenómenos psicológicos pueden ser encontrados en diferentes tradiciones, como la fenomenología existencial M. Merleau-Ponty, y el conductismo radical de B.F. Skinner. En este trabajo se pretende dar a conocer la crítica del pensamiento causal, discutiendo su papel clave en el enfoque de la conducta como un fenómeno con su propio sentido, como pretendido en esas dos perspectivas. En ambos enfoques, explicar no es encontrar las causas, sino que describir la estructura de la conducta, para Merleau-Ponty, o las contingencias de reforzamiento, para Skinner. En este sentido, se indica esta posición crítica como elemento favorecedor de aproximaciones posibles y diálogos entre estas diferentes perspectivas.

Palabras clave: Causalidad, explicación, Skinner, Merleau-Ponty.

\section{Similarities between Merleau-Ponty's Phenomenology and Skinner's Behaviorism}

Proposing dialogues between phenomenology and behaviorism is controversial, yet it enjoys favorable recommendations (e.g., Abib, 1988; Kvale \& Grenness, 1967; Pérez-Alvarez \& Sass, 2008; Wann, 1964). The book Behaviorism and Phenomenology: Contrasting Bases for Modern Psychology (Wann, 1964) is one of the most famous and celebrated publications concerning this discussion. Organized based on a symposium held at Rice University in 1963, the book compiles texts regarding the speeches of phenomenological psychologists (C. Rogers and R. B. McLeod), radical behaviorists (B. F. Skinner) and philosophers of science (N. Malcom and M. Scriven). Based both on such speeches and on the published book, at least two articles (Day, 1969; Giorgi, 1975) were dedicated to this issue in behavior analytic journals, commenting on the possibilities of dialogue and conciliation between Phenomenology and Behaviorism.

Nonetheless, on the whole, the records of the speeches at the symposium and the articles of the aforementioned commentators exhibit only a small number of considerations that reveal a pertinent comprehension, by both sides, of the fundamentals of each proposal. Even more so, to Kvale and Grenness (1967), the American version of existential phenomenology that was presented in the debate, which was mainly developed in a clinical environment, exhibits strikingly idealistic, subjective and voluntaristic interpretations that are incompatible with the notions expressed in the phenomenologicalexistential proposals of, for example, J. P. Sartre and M. Merleau-Ponty. Hence, the American version's opposition to radical behaviorism does not extend to the latter's relationship with the European version of phenomenology. As observed by Abib (1988), "The U. S. debate on behaviorism and phenomenology (published in 1964 by T. W. Wann, entitled 'Behaviorism and Phenomenology'), which enjoyed Skinner's participation, came short of expectations" (p. 426).

Disagreeing with the considerations presented at the aforementioned symposium, Kvale and Grenness (1967) highlight the closeness and productiveness of the confrontation between the metapsychological proposals revealed in the works of Merleau-Ponty (e.g., 1945/1994, 1942/2006) and Sartre (e.g., 1939/1948, 1940/1972) and those of Skinner (e.g., 1957, 1953/1965, 1974/1976). The key elements characterizing the similarity between these authors' stances would be the following: (a) the connection between the comprehension of the operant and the notion of directionality and action in 
the world; (b) the criticism of subjectivism and mentalism; and (c) the resulting queries and proposals to surmount the dualism introduced into psychology by the mentalist and physicalist traditions.

The development of such metapsychological models largely entails viewing behavior as an object of study for dealing with psychological phenomena. Widely recognized in the Skinnerian behaviorist approach, such a perspective can also be found in Sartre and Merleau-Ponty's phenomenological-existential approach. As pointed out by Kvale and Grenness (1967), "While Husserl and older phenomenologists focused upon the intentionality of consciousness, MerleauPonty and Sartre have stressed the intentionality of behavior - man's basic relatedness to the world" (p. 137).

Considering the point of view that sees the field of psychology as a behavioral field, Merleau-Ponty (1942/2006) claimed that psychological trends along these lines would have their potential hindered by their commitment to problematic philosophical foundations such as realism, atomism and causal thinking.

Concurrently, presenting his proposal to develop a behavioral science based on the experimental examination of this issue in its own right and domain, Skinner critically analyzed the traditions of reflexology and classical behaviorism. He claimed that, although they represent an important advance, these approaches have also produced the negative effect of discouraging a "descriptive attack" on behavior itself by focusing discussions and studies of psychological phenomena on "physical dimensions" (Skinner, $1938 / 1966$, p. 4), given the emphasis of such approaches on a mechanical-linear causal explanation, attributing a "controlling entity" role to the nervous system (Skinner, 1938/1966, p. 4).

In light of this situation, the present article aims to present and discuss the possibility that the criticism and overcoming of causal thinking be included in the list of metapsychological proposals that are common to the European phenomenological-existential perspective and the radical behaviorist approach (Kvale \& Grenness, 1967). Based on both Merleau-Ponty's work
(1942/2006) dedicated to examining the notion of behavior (The Structure of Behavior) and Skinner's texts (1957, 1931/1961, 1953/1965, $1938 / 1966,1981 / 1984)$ related to the issue of explaining behavior, we hereby present an analysis of these authors' criticism of causal logic in their discussions concerning the approach to psychological phenomena. In order to do this, we present a brief analysis of the causality issue in Philosophy of Science and in Psychology, aiming at establishing the causal-explanation definition to be employed in our assessment of Merleau-Ponty and Skinner's proposals.

\section{Explanation and Causality in Philosophy of Science}

The connection between explanations and causes has been longstanding and strongly supported throughout the history of philosophy. It had already been sign posted by Plato (essences that explain appearances); established as a possibility for "scientific knowledge" by Aristotle; and presented as a prerequisite for all forms of knowledge by Kant (Laurenti \& Lopes, 2008). As a general rule, this connection was rarely criticized throughout the history of philosophy until the twentieth century. Questions were raised as to its conditions, types, characteristics and definitions (Laurenti \& Lopes, 2008), but were infrequently raised with respect to its relevance, to the extent of discerning the possibility of its complete exclusion. Along these lines, in philosophy and science and in terms of common sense, finding an explanation has traditionally been interpreted as discovering causes.

Nonetheless, along with critical revisions of the philosophical and practical foundations of science, which were most intensely implemented as of the twentieth century, there are also questions that threaten the consensus concerning the connection between scientific explanation and causality (Laurenti, 2009). For example, Mach (1886/1959) claimed that causal explanations would be a very limited and imprecise way of dealing with the interdependence between events in nature. As an alternative, he proposed a functional understanding of the relationship 
between events - a notion he believed to offer greater precision and flexibility.

Another criticism of the causal model of scientific explanation was presented by Hempel (1965). He argued that a scientific explanation does not necessarily imply identifying causes, as can be observed in explanations based on taxonomic or statistical laws. On the other hand, the identification of causes is not observed exclusively in scientific explanations. Mythological and religious explanations also frequently involve causal discussions. To the author, causal laws would thus be one of the types of laws involved in scientific explanations, but not the only type.

In a similar manner, Bunge (1959/1963) argued that even if causal explanations are considered a paradigmatic example of scientific explanation, they are not the only way to answer the "whys" of such inquiries. Commenting on this perspective, Laurenti and Lopes (2008) affirm that, "there are other non-causal ways of explaining reality (e.g., statistical, dialectical, teleological and functional) that express increasingly complex, dynamic forms of relationships between processes and events" (p. 384). According to Bunge, from an ontological standpoint, discussions of causality would only apply to cases involving linear, unilateral and necessary relationships.

One could argue that such criticisms of causality are not applicable to all interpretations of the term. Nonetheless, through them, it can be perceived that one cannot assume that all relationships of dependence between events, established in scientific explanations, are causal (although of different types). On the contrary, the notion of a causal relationship (or dependence) would be tautological and meaningless: "employing the term 'causal' only makes sense if we admit that non-causal dependent relationships exist" (Laurenti \& Lopes, 2008, p. 385).

In order to conduct a more in-depth discussion of this subject, it is thus necessary a) to assume that non-causal dependent relationships between events exist; and b) to adopt a specific definition of causality, as a point of reference for discussions and criticisms to be conducted. In the present study, following the example of Laurenti and Lopes (2008), we employ the definition of causality proposed by Bunge (1959/1963).

To Bunge (1959/1963), the following principles are relevant to the notion of causality:

1. Conditionality (the occurrence of the event depends on the occurrence of certain conditions;

2. Uniqueness of the causal link ("one-to-one" correspondence between cause and effect an event can only be the cause of a single effect, and vice versa;

3. Necessary connection between cause and effect (one event causes the other: whenever one occurs, the other invariably occurs);

4. Unilateral dependence (the cause is an agent, and the effect is passive in the relationship between the events); and

5. Genetic connection (the cause is generative, the effect is a product - "the origin of something is explained by referring to its cause").

\section{Causality and Psychological Science}

From the perspective both of the Positivist tradition and of the technological advances and achievements of the so-called "hard sciences" in the eighteenth and nineteenth centuries, the challenge posed to the first proposals to create a scientific form of Psychology was to discover a way to define its field of analysis and specify its object of study in a manner compatible with the canons of "scientificity," such as direct observability and measurement. How can one scientifically deal with something that, ever since the very first considerations of the possibilities of knowledge (which somehow culminated in organized scientific thought), had been separated, excluded or isolated as something of a distinct nature, but was still viewed by many as a source of errors and deviations, an evil to be avoided or circumvented? In short, how can one create logos concerning the psyché?

Several movements along these lines sought, in the psychic ocean, safe islands, phenomena that could be quantified and measured using methods and instruments that are similar to 
those of current sciences, commonly referred to as "natural sciences." Together with such methods and instruments, philosophical perspectives and foundations (such as atomist, mechanistic, and realist concepts) were adopted.

Such movements also embraced a certain notion as to science's purpose: to explain the world by discovering the causes of phenomena. This was an attempt to apply to psychological phenomena the explanatory logic employed to understand objects. If objects could be understood by way of breaking them down into smaller elementary parts, then the same should apply to the processes existing in organisms' relationships with the world. Based on this conception, scientific proposals in the field of psychology defined psychological phenomena as a partes extra partes composition, seeking to discover which determinable laws governed a psychic element (determined and capable of independence) that triggered the operation of the next element, which in turn triggered the following element, in a chain of causes and effects (causal chain) that comprised the psychological phenomenon.

Among the various candidates for the object of study, such as consciousness data and elementary sensations, the movements of organisms were chosen in the wake of a long tradition of research in physiological sciences, which had already laid the groundwork for a theory of reflex behavior (Pessotti, 1982). Heir to this tradition, behaviorism proposed a restructuring of the understanding of psychic phenomena. Among such phenomena, it was necessary to choose those that could be described in physical terms. Explanations would be made by breaking such phenomena down into relationships between stimuli (physical events in the world) and responses (behavioral events, physiological reactions of organisms).

In contrast with reducing psychic phenomena to physical phenomena, other proposed approaches were based on the exact opposite: psychic phenomena possess a distinct mental nature that is either inaccessible or merely indirectly accessible by the natural sciences. As affirmed by Japiassu (1977), knowledge concerning human nature seemed to oscillate

... between an organicistic, materialistic knowledge of man's physical, biological being and a spiritualistic knowledge of the human soul's psychic, intellectual and moral nature, linking the two forms of knowledge in a relatively illegitimate manner in the field of objectivity. (p. 24)

Critically analyzing the various conceptions of behavior and perception, Merleau-Ponty's early research (1945/1994, 1942/2006) examines precisely this context. Also faced with the same impasse, yet experiencing it within the context of the behaviorist tradition itself, B. F. Skinner developed the analytical-behavioral approach (e.g., 1953/1965, 1971, 1974/1976).

As mentioned by Hidalgo (2017), despite their distinct objectives, Skinner and MerleauPonty share not only the elaboration of reflections "on the philosophical status of the notion of behavior," but also sensitivity "to similar theoretical questions, such as the inadequacy of the principles of classical reflexology to explain behavior," likewise proposing to elaborate a "notion of behavior in its own territory [and thus incapable of being reduced to physiology]" (Hidalgo, 2017, p. 161). Along these lines, in both Merleau-Ponty and Skinner's research, one finds the development of an understanding of behavior that, seeking to repel the phantasms of intellectualistic approaches (mentalism), criticizes the insufficiencies and limitations of the early twentieth century's theories as to reflexology and conditioned behavior. Among such criticisms, we highlight, in the following sections, those that are relevant to the causal explanatory model.

\section{Merleau-Ponty's Criticism of the Use of Linear Causality to Explain Behavior}

Merleau-Ponty's philosophical perspective of surmounting classical metaphysics' dichotomies (subjective-objective, internal-external, mind-body) in order to understand the human 
phenomenon found fertile ground in psychology. As pointed out by Verissimo and Furlan (2007), in his first major study (The Structure of Behavior), Merleau-Ponty "initiated a rigorous, critical, systematic debate with the realism of scientific psychology" (p. 334). Resorting to interpretations and arguments in the research of Goldstein, Koffka and Köhler, Merleau-Ponty (1942/2006) emphasized the notion of form ( $\mathrm{Ge}$ stalt) as a possibility of overcoming the objectivistic, reductionist perspective of reflex theories (e.g., Sherington, Pavlov, Watson), yet without abandoning the empirical field in favor of idealistic or rationalistic assertions.

Recognition of the failure of psychology's physicalist (objective) approach would not represent, however, an indication of a return to the mentalist (idealist, subjectivist) perspectives. Along these lines, Merleau-Ponty (1942/2006) advocated the notion that the behavioral concept is essential for dealing with psychological phenomena. Directly accessible and objectively describable, the behavioral concept, "taken in itself," would be the way to redefine "psychism" and "physiological" in order to surmount the traditional dichotomies commonly related to them (Merleau-Ponty, 1942/2006, p. 3).

To Merleau-Ponty (1942/2006), the notion conveyed by the reflex tradition in psychology was that the organism is a "partes extra partes" material mass" (p. 2) whose behaviors would result from pre-established connections. Phenomena were seen as combinations of independent elements; and they were explained by describing external, mechanical relationships. Behavior was explained by defining the linear dependencies between stimuli and receptors, and between receptors and effectors. Behavior was believed to consist of units that associate and disassociate themselves according to laws governing the physical properties of the elements involved (e.g., sensory modality, intensity, location, frequency, duration). From this perspective, the excitation resulting from the stimuli would be the cause of the behavior (effect), "in the empirical sense of a constant and unconditioned antecedent" (Merleau-Ponty, 1942/2006, p. 8). Passive, the organism would carry out that which was prescribed by the excitation.

Within the context portrayed by classical reflex theories, psychological phenomena are reduced to reflex behaviors, taken as longitudinal phenomena of certain physical or chemical agents' operations on a specific receptor, provoking a certain response. According to Merleau-Ponty, one of the reasons for the difficulties and inadequacy of the behavioristic approach is precisely its attempt to preserve the notion of phenomena being an association between realities (real stimulus and real movement), which nonetheless remained immune to this association.

Merleau-Ponty's (1942/2006) criticism of the approaches of reflexology and behaviorism is largely based on the arguments developed by Gestalt psychologists. Examining the analyses and discussions of authors like Koffka (1925, $1935)$ and Köhler (1927, 1930), Merleau-Ponty emphasized that the scenario portrayed by reflex theories could not withstand an examination of the data produced by experimental psychology and had to constantly resort to ad hoc postulates, usually outside of the behavioral field, in order to try to construct an intelligible interpretation of this association.

In both research involving humans and studies concerning non-humans, the authors of the "Berlin School" demonstrated that the arrangement of one element in relation to the others alters the manner in which the organism interacts or relates with it. A stimulus is never understood without its context, in terms of its real parts, independently; instead, this always occurs within a context, a situation, in which nothing is gained (in terms of comprehending the phenomenon) from the description of its actual properties, from the description of the stimulus "in itself," but rather from the description of the structure that conforms to the conduct: "In view of the fact that breaking something down into its real parts is an endless endeavor, the stimulus never becomes reflexogenic as an individual physical reality; it always becomes reflexogenic as a structure" (Merleau-Ponty, 1942/2006, p. 162). 
As examples, Merleau-Ponty (1942/2006) cited both experiments employing the Jastrow Illusion and research involving lighting and compositions with distinct colors. ${ }^{1}$ In MerleauPonty's point of view, the results of such studies would demonstrate that an exciter could not be conceived as a discrete, causative stimulus; rather, it should be conceived as a situation, a context or even a structure:

The true exciter of conditioned reactions is neither a sound nor an object considered individually, nor a combination of sounds or objects viewed as sets that are simultaneously individual and chaotic, but rather the distribution of sounds over time, their melodic sequence, the reactions of magnitude of objects; as a general rule, the structure necessitates the situation. (Merleau-Ponty, 1942/2006, pp. 83-84)

In spite of the advances in relation to developing a structural form of thinking that opposes the analytical thinking that dominated reflex theories, Merleau-Ponty (1942/2006) argued that Gestalt theory falls into the trap of the polarized thought of a "philosophy of substance," as if it needed to choose between discovering its elements in a material or non-material substance. Again favoring the physicalist view as a defense and guarantee of scientificity, Gestalt theory ends up treating form as substance, once more attempting to make the physical dimension "the true foundation of behavior" and of the "perceptual structure" (Merleau-Ponty, 1942/2006, p. $225)$; in other words, it attempts to make physical structures the cause of perceived structures.

Merleau-Ponty discusses various experiments presented by Köhler in which animals were trained to choose the smaller of two figures, or a certain color, or even a certain gradient of color, in order to obtain food after each correct response. When placed before two figures that were identical yet were positioned so that one appeared to be smaller than the other (or before identically colored disks that, due to the lighting conditions, appeared to exhibit different colors or color gradients), the animals systematically chose the figure that, to human perception, appeared smaller or appeared to exhibit the color or color gradient that the animal was trained to perceive.
Opposing the reification of atomistic conceptions, Gestalt theory ends up resorting to a reification of forms or structures, committing itself to precisely the same problematic foundations of the reflex theories that it criticizes (MerleauPonty, 1942/2006).

As pointed out by Verissimo (2012), to Merleau-Ponty, what is at stake is the living (not the psychophysical) aspect of the concept of structure. Psychology can discover the meaning of behavior by examining the reorganization of an organism's relationship with the environment, or by examining such organization within the vital, human domain, not by examining an awkward reproduction of the physical domain's organization, as conditioned-reflex theories have sought to do. In light of the fact that the relationships established between an individual and the world are oriented in accordance with the significant unity operated by an organism in its environment, and that this meaningful unity is only understood in the world that is perceived, "What is perceived would only be explainable in terms of what itself is perceived, and not in terms of physiological processes" (Merleau-Ponty, $1942 / 2006$, p. 145). This means radicalizing the conception of structure in a true "philosophy of form" (Merleau-Ponty, 1942/2006, p. 206), so as to comprehend behavior as "a dialectical, meaningful connection between the organism and its environment, a relationship involving reciprocity and interactivity" (Verissimo \& Furlan, 2007, p. 336).

Hence, to Merleau-Ponty (1942/2006), behavior implies a dialectical relationship, that is, a relationship of reciprocity, interactivity and mutual adjustment, between the organism and it $\mathrm{s}^{2}$ environment. Consequently, the method involving real analysis and causal explanations - which is relevant to the way in which physi-

Here, the possessive pronoun is highlighted in order to explain that, from this perspective, the organism is not related to "any" environment (i.e. to a real or objective environment), but rather to an environment already constituted by this relationship (i.e. dependent on the relationship, dependent on the organism), which is thus its environment. 
calistic approaches have attempted to structure the relationships between the elements of actions - is unfruitful with respect to attempts to construct an understanding of behavior within its own field. In a manner quite similar to Bunge's description (1959/1963) of the causal concept, Merleau-Ponty characterizes the causal model implied in reflex theory to explain behavior, as follows:

Regardless of whether we consider it in a limited sense or in a broad sense, the term "mechanical action" refers to an action in which the cause and the effect can be broken down into real elements that correspond to each other on a one-to-one basis [uniqueness of the causal link]. Elementary actions involve one-way [unilateral] dependence, whereby the cause is a necessary condition of the effect [necessary connection] considered in terms of its existence and nature [genetic connection]; and, even when one speaks of the reciprocal action between two terms, such an action can be reduced to a series of one-way determinations. (MerleauPonty, 1942/2006, p. 250)

As a basis for ordering the relationship between organisms and the world, the structural concept is incompatible with the mechanistic conception of behavior, thus ruling out discussions of it based on the causal explanatory model. Along these lines, in a note in the introduction to The Structure of Behavior, Merleau-Ponty points out that the notion of behavior, as initially proposed by Watson, "could only receive its philosophical status if causal or mechanical thinking were abandoned in favor of dialectical thought" (Merleau-Ponty, 1942/2006, p. 4, note $3)$. Hence, understanding behavior is possible inasmuch as "we relinquish both mechanistic and finalistic realism, that is, all forms of causal thinking [emphasis added]" (Merleau-Ponty, 1942/2006, p. 76).

The significance of behavior would thus be discovered via synthesis, not via analysis. Merleau-Ponty (1942/2006) indicated that the approach to behavior should be guided by thinking in terms of function or meaning, instead of thinking in terms of causes: "We have seen, for example, that two dissimilar stimuli are fused in eyesight if they serve the same function [emphasis added] in both colored regions, that is, the function of 'a point in front of a homogeneous background"” (Merleau-Ponty, 1942/2006, p. 145). Furthermore:

It is not because two retinal stimuli are embedded in the same associative circuit that their psychic correspondents receive the same function in perceived space; on the contrary, it is this common function that designates them to be connected by an associative circuit. Coordination itself emerges as a result: the effect of a phenomenon of structure or "form". (Merleau-Ponty, 1942/2006, p. 125)

Employing Bunge's definition of causality (1959/1963), one can find, in Merleau-Ponty's critical proposal (1942/2006), the overcoming of each one of its characteristics:

In contrast, as we have seen, physical stimuli only act upon the organism by causing in it a global response that varies qualitatively when they vary quantitatively [against the "uniqueness of the causal link"]; in relation to the organism, they play the role of occasions rather than causes [against the "necessary connection"]; the reaction depends more on the vital significance of the stimuli than on their material properties. Thus, among the variables upon which conduct and this conduct in particular actually depend, there appears a meaningful relationship, an intrinsic relationship [against the "genetic connection"]. We cannot pinpoint the moment in which the world acts upon the organism, for the very effect of such 'action' expresses the organism's inner law [against "unilateral dependence"]. At the same time that the mutual exteriority of the stimuli is overcome, the mutual exteriority of the organism and its environment is also overcome. Defined separately, these two terms must thus be replaced by two correlated terms, "environment" and "aptitude", which are like two extremities of behavior 
that participate in the same structure. (pp. 250-251)

The only thing remaining would be the character of conditionality, for which a positive indication can in fact be found. Nonetheless, indicating certain conditions upon which an event would depend in no way reintroduces atomistic causal thinking. According to Merleau-Ponty (1945/2006), such an indication only reflects the description of the ordering of behavior, and "it makes no sense if we transform it into a problem of causality" (p. 74). An explanation of the behavioral field is not a search for the cause of behavior - events simply occur when the necessary conditions are present (Merleau-Ponty, 1945/2006).

Seeking to offer an understanding of behavior from Merleau-Ponty's perspective, one could say that behavior has meaning, direction and intentionality - "Intentional behavior is directed toward the world, it acts upon the world and reveals this world to man" (Kvale \& Grenness, 1967, p. 137). However, one cannot say that it has a cause (in the strict sense of the term), at least not in terms of Bunge's definition $(1959 / 1963)$. There is no external agent that leads or forces the body to act; there is likewise no need to resort to an internal agent as a driving force, nor is there room for such an internal agent to concentrate the meanings and intentions - they already are a part of the behavior, which is seen as a dialectical relationship between the organism and the world.

Along these lines, criticism of the concept of linear causality that supports classical reflex theory and its derivations in physiology and psychology can be seen as one of the key aspects for discussions of the notion of behavior and for the questions Merleau-Ponty posed to Psychology in relation to "its methods, its scope and the notion of being that emerges from it" (Verissimo \& Furlan, 2007, p. 332). From this standpoint, it follows that, according to the conception proposed by Merleau-Ponty in The Structure of Behavior, explaining behavior does not signify identifying its causes as if they were unrelated to it (as in classical reflex theory), but rather describing "the constitution of 'forms' or functional structures" (MerleauPonty, 1942/2006, p. 139).

\section{Skinner's Proposal for an Explanation of Behavior and Criticism of Causality}

The fact that B. F. Skinner's name is identified with the classical behaviorist approach is a recurrent source of confusion, misunderstandings and biases as to this American psychologist's proposal (e.g., Carrara, 2005; Chiesa, 1994). Influenced by the behaviorist tradition, in his early research Skinner (1931/1961, 1938/1966) studied the conditioned-reflex approach to behavior, yet he already discerned distinctions between an organism's types of responses, a fact that lead him to propose the creation of a different kind of behavioral concept and interpretation: the operant theory. Emphasizing the differences in relation to reflex theories, several authors (e.g., Abib, 2004; Chiesa, 1994) question the appropriateness of Skinner's proposed approach being identified with the same nomenclature (implying the notion of belonging to the same tradition) as that of proposals such as those of Pavlov and Watson.

Among the most striking differences between Skinner's radical behavioral stance and the traditional approaches of reflexology and behaviorism, the emphasis on the relationship between the organism's action and the environment subsequent to such action stands out. These are the so-called consequences of the behavior, which have a reinforcing effect when followed by an increase in the rate of responses, and a punitive effect when followed by a decrease, thus characterizing the new type of behavior, operant; they indicate the possibility of a behavioral proposal focused on the "field of purpose and intention" (Skinner, 1938/1966, p. xxii, 1974/1976, p. 55).

Unlike the traditional behaviorist approach, in Skinner's approach the environment has the role of selecting actions, not causing them. There is no "sting" - "the reflex concept must be voided of all connotations of an active 'thrust' on the part of the stimulus" (Skinner, 1938/1966, 
p. 21). The environment acts as a context (prior and subsequent), interacting with the organism - "Human beings act upon the world, modify it and, in turn, are modified by the consequences of their actions" (Skinner, 1957, p. 1).

Admittedly influenced by E. Mach's work, Skinner (1931/1961) already affirmed in one of his early works that, in his proposal of a behavioral science, "the concept of causation is replaced by that of function" (p. 338). Along these lines, in terms of radical behaviorism,

A "cause" becomes a "change in the independent variable" and an "effect" a "change in the dependent variable". The old "causeand-effect connection" becomes a "functional relationship". The new terms do not suggest how a cause causes its effect; they merely asserts that different events tend to occur together in a certain order. (Skinner, $1953 / 1965$, p. 23)

Another striking aspect of Skinner's proposal (which can also be attributed to the influence of Mach's work and, principally, to Darwinian thought) is its selective character. Skinner (1981/1984) calls his explanatory system ${ }^{3}$ "a model of selection by consequence." The explanation of human behavior would occur at three levels: phylogenetic, ontogenetic and cultural. At all three levels, the environment does not cause a response; instead, it alters the probability of future occurrences, that is, it selects and reinforces (in the sense of "makes more probable") the relationship between a class of stimuli and a class of responses, regardless of whether the class of responses is at the level of species survival, the level of the persistence of the conduct or the level of the maintenance of a cultural practice. In this sense, one may say that a response was selected when such a response, within a certain context,

In the text cited here (Selection by Consequences), Skinner (1981/1984) states that the selectionby-consequences model is the "causal model" of radical behaviorism. As is discussed in the next section, here one sees an example of the confusion and inconsistency of the author's writing with respect to the notion of causation, which, in this case, seems to indicate the notion of an "explanatory model." operates on the environment, in such a manner that a change in the environment that follows it increases such a relationship's probability of occurrence (prior context - response - subsequent context) in future opportunities.

Nonetheless, in spite of clearly affirming his awareness of the need to abandon the causal explanatory model (Skinner, 1931/1961, 1953/1965) and constructing his proposal based on a concept of behavior that is incompatible with such logic, there are moments in Skinner's work in which he employs the term "cause" (and its variations) as an equivalent for "explanation" (Skinner, 1981/1984) or as a manner of expressing the connection between events in behavioral relationships (e.g., Skinner 1969, ${ }^{4} 1985^{5}$ ). Nonetheless, the confusing presence of such expressions can be minimized by his emphasis on the functional selectionist conception of behavior, the path he designated for abandoning the causal model. Endorsing this perspective, Laurenti and Lopes (2008) compared the categories Bunge (1959/1963) indicated as defining the causal logic with those indicated by the Skinnerian approach.

With respect to the "uniqueness of the causal link," for example, one observes that Skinner's explanation of behavior in terms of dependent and independent variables does not exhibit this characteristic. An independent variable can be associated with different events or can function in different manners, assuming different functions. The same holds for dependent variables, which can be related to different events - they can be a function of distinct variables.

Along these lines, the "necessary connection" condition is also not observed in Skinner's proposed approach, for the dependent variable refers to the probability of occurrence of a given response, not to the response itself. In other words, the independent variable's existence does not imply the compulsory alteration of a certain

4 "But the feelings are at best accompaniments of the behavior, not causes" (Skinner, 1969, p. 257).

5 "If we assume that what is felt are products of the causes of behaviour, feelings can be useful clues to those causes" (Skinner, 1985, p. 300). 
dependent variable; what one observes is analteration in the probability that such a response (dependent variable) occurs. The relationship between the variables at issue "is flexible and continuously gradual” (Skinner, 1953/1965, p. 110).

Skinner's proposal also does not conform to the "unilateral dependence" implied in the concept of causation. The elements that are involved - organism and environment - exhibit a recursive, not a unilateral, relationship. They act upon each other, mutually influencing each other and even determining their definition: "definition: "Neither term may be defined as to its essential properties without the other" (Skinner, $1938 / 1966$, p. 9). There is no emphasis on either of them, but rather on their relationship.

Lastly, in Skinner's proposed approach, one does not observe a "genetic connection" between the cause (generator) and the effect (product). In radical behaviorism, behavior is explained in terms of the order in which the elements are regularly related, without such an order implying that the former event generates or causes the latter (Skinner, 1953/1965).

Concerning the element of conditionality in Bunge's definition (1959/1963), one observes a positive indication in Skinner's proposal, as mentioned in the case of Merleau-Ponty; and, as indicated for Merleau-Ponty's proposal, the existence of such a characteristic does not imply a commitment to the causal perspective. Conditionality is incorporated into Skinner's proposal as a characterization of the relationship formed between an action and the environment by way of the process of reinforcement. Conditionality denotes the fact that such a relationship "did not exist until the operation of reinforcement had been performed" (Skinner, 1938/1966, p. 61). In this sense, Skinner points out that, to describe behavior, the French term conditionnel [conditional] would better represent the intended meaning of the English term "conditioned".

As concluded by Laurenti and Lopes (2008), one could argue that, in Skinner's analytic-behavioral approach, there is a strong tendency toward overcoming causal thinking, at least as
Bunge defined it (1959/1963). Along these lines, in Skinner, we also observe the overcoming of the notion that causality is a characteristic, distinctive trait of his proposed approach to explaining behavior.

\section{Final Considerations}

Examining the notion of behavior as a fundamental concept in Merleau-Ponty's first book (1942/2006), which was dedicated to this theme, we observe the centrality of overcoming, and of criticism of, the causal explanatory method. The [re] arrangement of this concept based on the notion of form necessarily entails abandoning the view that the relationship between an organism and the world is formed in a causal chain of discrete mechanical events.

In a similar manner, one also observes that, differing from the reflex tradition, Skinner's operant theory exhibits a relational understanding of behavior. In light of the fact that an organism's responses and the environment's stimuli are linked in a functional manner, it makes no sense to speak in terms of causes of behavior. The environment does not cause the organism's behavior; instead, it selects the behavior via its consequences, strengthening the ties between a class of stimuli and a class of responses, which are functionally determined.

Corroborating this interpretation, we perceived that, in light of Bunge's definition (1959/1963), both Merleau-Ponty and Skinner's proposals present no characteristics that define the causal explanatory model. Based on the discussions and arguments of the analysis we performed, we recommend adding another item to the list of metapsychological proposals that are common to the European phenomenological-existential perspective and the radical behaviorist approach (Kvale \& Grenness, 1967): the criticism and abandonment of linear causal notions for explaining behavior.

In Merleau-Ponty's phenomenologicalexistential approach and in Skinner's radical behaviorism, we perceive both an indication of causal linearity's inadequacy to deal with the 
complexity and fluidity of the behavioral phenomenon and a criticism of the causal approach as a revelation of what is real, of some hidden mechanism, "non-apparent," or "non-sensitive." Accordingly, it can be affirmed that, in both approaches, explaining behavior does not signify discovering the causes of behavior, but rather describing the structure of behavior, according to Merleau-Ponty (Furlan, 2000), or describing the contingencies of reinforcement, according to Skinner (Laurenti \& Lopes, 2009).

\section{References}

Abib, J. A. D. (1988). Comportamento, Subjetividade e Sentido. In Anais da XVIII Reunião Anual de Psicologia de Ribeirão Preto (pp. 419-427). Ribeirão Preto, SP: Sociedade de Psicologia de Ribeirão Preto.

Abib, J. A. D. (2004). O que é comportamentalismo? In M. Z. S. Brandão, F. C. S. Conte, F. S. Brandão, I. K. Ingberman, V. L. M. da Silva, \& S. M. Oliani (Eds.), Sobre comportamento e cognição: Vol. 13. Contingências e metacontingências: Contextos socioverbais e o comportamento do terapeuta (pp. 52-61). Santo André, SP: Esetec.

Bunge, M. (1963). Causality: The place of the causal principle in modern science. New York: The World Publishing Company. (Original work published 1959)

Carrara, K. (2005). Behaviorismo radical: Crítica e metacrítica. São Paulo, SP: Editora da Universidade Estadual Paulista "Júlio de Mesquita Filho".

Chiesa, M. (1994). Radical behaviorism: The philosophy and the science. Boston, MA: Authors Cooperative.

Day, W. F. (1969). Radical behaviorism in reconciliation with phenomenology. Journal of the Experimental Analysis of Behavior, 12, 315-328.

Furlan, R. (2000). A noção de "comportamento" na Filosofia de Merleau-Ponty. Estudos de Psicologia (Natal), 5(2), 383-400. doi:http://dx.doi. org/10.1590/S1413-294X2000000200005

Giorgi, A. (1975). Convergences and divergences between phenomenological psychology and behaviorism: A beginning dialogue. Behaviorism, $3(2), 200-212$.
Hidalgo, M. (2017). Behaviorismo e fenomenologia? Notas sobre Merleau-Ponty e Skinner. In I. de O. Caminha \& A. J. Abath (Eds.), Merleau-Ponty e a psicologia (pp. 161-172). São Paulo, SP: LiberArs.

Hempel, C. (1965). Aspects of scientific explanation and other essays in the philosophy of science. New York: Free Press.

Japiassu, H. (1977). Introdução à epistemologia da psicologia ( $2^{\text {nd }}$ ed.). Rio de Janeiro, RJ: Imago.

Koffka, K. (1925). The Growth of the Mind. London: Kegan Paul, Trench, Trubner and Co.

Koffka, K. (1935). Principles of Gestalt Psychology. London: Kegan Paul, Tench, Trubner and Co.

Köhler, W. (1927). The mentality of apes. London: Routledge.

Köhler, W. (1930). Gestalt Psychology. London: G. Bell.

Kvale, S., \& Grenness, C. E. (1967). Skinner and Sartre: Toward a radical phenomenology of behaviorism? Review of Existential Psychology and Psychiatry, 7, 128-150.

Laurenti, C. (2009). Criatividade, liberdade e dignidade: Impactos do darwinismo no behaviorismo radical.Scientice Studia, 7(2), 251-269. doi:http:// dx.doi.org/10.1590/S1678-31662009000200006

Laurenti, C., \& Lopes, C. E. (2008). Uma explicação não-causal do comportamento no behaviorismo radical. Acta Comportamentalia, 16(3), 379-397.

Laurenti, C., \& Lopes, C. E. (2009). Explicação e descrição no Behaviorismo Radical. Psicologia: Teoria e Pesquisa, 25(1), 129-136. doi:http:// dx.doi.org/10.1590/S0102-37722009000100015

Mach, E. (1959). The analysis of sensations (C. M. Williams, Trans.). New York: Dover. (Original work published 1886)

Merleau-Ponty, M. (2006). A estrutura do comportamento (M. V. M. de Aguiar, Trans.). São Paulo, SP: Martins Fontes. (Original work published 1942)

Merleau-Ponty, M. (1994). Fenomenologia da percepção (C. A. R. de Moura, Trans.). São Paulo, SP: Martins Fontes (Original work published 1945)

Pérez-Alvarez, M., \& Sass, L. A. (2008). Phenomenology and Behaviorism: A mutual readjustment. Philosophy, Psychiatry \& Psychology, 15(3), 199-210. 
Pessotti, I. (1982). Movimento muscular e comportamento: Notas históricas. In B. Prado Jr. (Ed.), Filosofia e comportamento (pp. 11-32). São Paulo, SP: Brasiliense.

Sartre, J.-P. (1948). The emotions: Outline of a theory. New York: Philosophical Library. (Original work published 1939)

Sartre, J.-P. (1972). The Psychology of Imagination. London: Methuen \& Co. (Original work published 1940)

Skinner, B. F. (1957). Verbal behavior. New York: Prentice-Hall.

Skinner, B. F. (1961). The concept of the reflex in the description of behavior. In B. F. Skinner (Ed.), Cumulative record (pp. 319-346). New York: Appleton-Century-Crofts. (Original work published 1931)

Skinner, B. F. (1965). Science and Human Behavior. New York: The Free Press. (Original work published 1953)

Skinner, B. F. (1966). The behavior of organisms. New York: Appleton-Century. (Original work published 1938)

Skinner, B. F. (1969). Contingencies of reinforcement: A theoretical analysis. New York: Appleton-Century-Crofts.

Skinner, B. F. (1971). Beyond freedom and dignity. New York: Alfred A. Knopf.
Skinner, B. F. (1976). About behaviorism. New York: Vintage Books. (Original work published 1974)

Skinner, B. F. (1984). Selection by consequences. The Behavioral and Brain Sciences, 7(4), 477481. (Original work published 1981)

Skinner, B. F. (1985). Cognitive science and behaviourism. British Journal of Psychology, 76, 291301. doi:10.1111/j.2044-8295.1985.tb01953.x

Verissimo, D. (2012). A primazia do corpo próprio: Posição e crítica da função simbólica nos primeiros trabalhos de Merleau-Ponty. São Paulo, SP: Editora da Universidade Estadual Paulista "Júlio de Mesquita Filho".

Verissimo, D. S., \& Furlan, R.(2007). Entre a filosofia e a ciência: Merleau-Ponty e a Psicologia. Paideia (Ribeirão Preto), 17, 331-342. doi:http://dx.doi. org/10.1590/S0103-863X2007000300004

Wann, T. W. (1964), Behaviorism and phenomenology: Contrasting bases for modern psychology. Chicago, IL: University of Chicago Press.

Received: 26/09/2016

$1^{\text {st }}$ revision: $30 / 12 / 2016$

Accepted: 08/02/2017

(C) The Author(s), 2018. Open Access. This article is distributed under the terms of the Creative Commons Attribution 4.0 International License (http://creativecommons.org/licenses/by/4.0/), which permits unrestricted use, distribution, and reproduction in any medium, provided you give appropriate credit to the original author(s) and the source, provide a link to the Creative Commons license, and indicate if changes were made. 